\title{
The mechanics of female sexual performance in the 16th century
}

\author{
Lesley Smith
}

\section{The pleasure principle}

Cleopatra, Salome and Casanova are names that remind us that history is full of sexual passion and desire. Power, beauty and money have all had their part to play in making an individual much more attractive. In the case of the Venetian Casanova it was his sexual skills as a lover that gave his reputation such force: it is said no woman could resist him.

Two centuries earlier, under the reign of Queen Elizabeth, people took great interest in the ability to provide sexual satisfaction for both men and women. For some, the very idea that our ancestors were even interested in the coital pleasures of women seems unlikely as society appeared to be only set out for the serving of male needs.

In truth, orgasm during copulation for both the man and woman was considered absolutely essential for conception to take place on the basis of a belief in dual ejaculation. This belief was entrenched in medical and midwifery practices based on the interpretation of the ancient medical philosophers such as Hippocrates and Galen.

\section{Anatomy lessons}

Female genitalia were considered to be directly analogous to male genitalia (Figure 1). The labia major were the empty scrotum sacks. The vagina was thought to be the penis - in reverse. There does some to be some level of contradiction in this theory, however, as experience proved that the penis was the sensitive pleasure organ in males whilst it was recognised that the clitoris was essential for pleasure in women, with or without a partner.

There are some early descriptions of the clitoris in Columbus and Fallopius. These anatomical reports make interesting reading: "Commonly it is but a small sprout, lying close hid under the Wings, and not easily felt, yet sometimes it grows so long that it hangs forth at the slit like a Yard, and will swell and stand stiff if it be provoked, and some lewd women have attempted to use it as men to theirs ...". The hermaphrodite condition was well known in medieval times and some believed that there was an additional chamber in the womb to hold such a child.

Since 16th century doctors and society in general understood that the clitoris had a pleasure-giving function and believed that pleasure was a vital part of conception; we also find reference to sexual techniques. Heat, the male predominating humour, was thought to be strongly aligned to passion - a reasonable conclusion in the vigorous heat of coitus and the visible, hot, red swelling of sexual organs in arousal. Red blotches on the skin and perspiration all gave further evidence. Women who showed signs of distaste in the marriage bed were described as "cold", a phrase that continues to be used to this day.

\section{Food of love}

Erotic imagery, alcohol and certain foods were all considered able to play their part in the process of arousal.

J Fam Plann Reprod Health Care 2009; 35(2): 127-128

Tutbury Castle, Tutbury, UK

Lesley Smith, Curator

Correspondence to: Lesley Smith, Tutbury Castle, Tutbury, Staffordshire DE13 9JF, UK. E-mail: info@tutburycastle.com

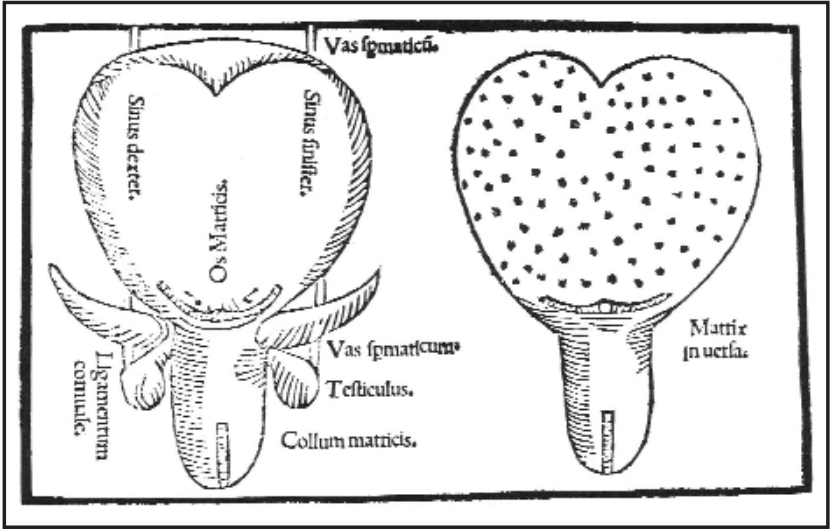

Figure 1 The uterus and ovaries, and the uterus shown internally (B. da Carpi: Isagoge breves 1522, f. 52r). Image reproduced with the kind permission of the Wellcome Library, London, UK

Casanova was reputed to carry with him a small burning stove to heat up hot chocolate in case he needed it in a hurry to help with his libido. He also carried tomatoes, which were considered aphrodisiac and described as "love apples". The 16th century equivalent of these foods were spices, mustard, peas and beans, although I haven't found any evidence that these items were carried around by individuals in case of sexual emergency.

The eating of peas and beans was thought to be particularly useful in helping to cause and sustain the male erection. Flatulence sounds an unlikely bedfellow in sexual allure but the actual breaking of wind was considered most helpful in making the penis become turgid. This seems to be a principle based on some type of anatomical rocket.

Whilst humorous to the modern observer, for those individuals trying to produce heirs conception was a very serious matter indeed, particularly as child mortality rates were so high.

God, particularly in the form of the Holy Ghost, was the mystical element of conception whilst the Devil and his demons pressed the pleasures of fornication through temptation. Miracles and divine punishment were not totally unexpected and recorded as such on occasions.

\section{Caught in the act}

There are recorded incidents of couples being caught in deeply embarrassing situations. In late medieval times the situation described in William Caxton's 1483 translation of Livre pour l'enseignement de ses filles du Chevalier de La Tour Landry ("Book of the Knight of the Tower") tells of divine retribution in punishment for blasphemy and fornication. It seems a man and woman were found underneath a church altar locked together. Unfortunately they remained locked under public gaze for most of the rest of the day to be viewed by any that chose to come and see them in their plight. As the day wore on and the couple still "could not depart one from the other", parishioners joined together and prayed to God and the saints to release them. This therapy apparently worked and the couple were able to part at last.

The man involved, Perrot Lanard, was sentenced by the Ecclesiastical Court to process naked around the Church 
each Sunday for three weeks beating himself and telling all of his sin. Men and women were liable to persecution for sexual misbehaviour in both secular and ecclesiastical courts but in this particular case it seems only Master Perrot was publicly punished.

\section{Sinful behaviour}

There was no opportunity to claim a private life and private choice about sexuality as now. You were either married and therefore involved in legitimate sexual behaviour or you were a sinner practising fornication, lewdness and even blasphemy. Incest, bestiality, paedophilia, rape and - in lesser sin terms - masturbation were all known, as were homosexual and lesbian relationships.

It seems that the super rich and powerful were almost exempt from censorship for sinful behaviour. Henry VIII did not seem to be much criticised for keeping a number of mistresses from as young an age as 14 years (if true) and parading his illegitimate offspring without fear of retribution. There does seem to be a clear divider about such behaviour amongst rich and powerful women as society needed to be clear about the identity of the father of the child carried by a woman of social standing and/or importance. One can well imagine before the availability of paternity testing the level of territorial disruption and claims for property and title possible if women were able to be free sexually with the risk of pregnancy. There were a large number of such cases even with this behavioural censorship in place. Our ancestors were highly litigious in the Tudor period.

\section{Sex equality}

Now we can see a pattern emerging that a woman in the 16th century should be God-fearing, modest in dress and behaviour and subservient to her husband. She should have a full understanding of womanly tasks such as housekeeping and medical skills, know how to train and control servants, and be able to produce healthy preferably male - children. Many readers will no doubt be pleased to learn that there were a number of significant women who held very few, if any of these 'ideal' attributes. We also find that far from having a downtrodden existence, many women were able to enjoy an active and satisfying sex life that involved not only an obligation for her to please her husband sexually but that he should make a real effort to ensure her sexual pleasure too.

\section{Future articles}

The next article in this series will be on Casanova.

\section{Acknowledgement}

The author would like to thank Dr G Williams, British Museum, London, UK for his help and advice.

\section{Bibliography}

1 Camille, Michael. The Medieval Art of Love: Objects and Subjects of Desire. London, UK: Laurence King Publishing, 1998.

2 McDonald, Nicola (ed.). Medieval Obscenities. York, UK: York Medieval Press, 2006.

3 Haynes, Alan. Sex in Elizabethan England. Stroud, UK: Sutton Publishing Ltd, 1997.

4 Herman, Eleanor. Sex With Kings. New York, NY: Harper Collins Publishers, 2004.

5 Markham, Gervase. The English Housewife. Montreal, Canada: McGill-Queen's University Press, 1986.

6 Burford, EJ and Wotton, Joy. Private Vices - Public Virtues: Bawdrey in London from Elizabethan Times to the Regency. London, UK: Robert Hale Ltd. 1995.

7 Byrne, Muriel St Clare (ed.). The Lisle Letters. Harmondsworth, UK: Penguin Books Ltd, 1985.

8 Eccles, Audrey. Obstetrics and Gynaecology in Tudor and Stuart England. London, UK: Croom Helm, 1982.

9 Maxwell-Stuart, PG (ed.). The Malleus Maleficarum. Manchester, UK: Manchester University Press, 2007.

10 Hopkins, Amanda and Rushton, Cory James (eds). The Erotic in the Literature of Medieval Britain. Cambridge, UK: D S Brewer, 2007.

11 Green, Monica H (ed.). The Trotula. Pittsburgh, PA: University of Pennsylvania Press, 2001.

12 Néret, Gilles. Erotica: 17-18th Century From Rembrandt to Fragonard. Los Angeles, CA: Taschen America, 2001.

About the author

Lesley Smith is currently a postgraduate student in the Centre for the History of Medicine of the University of Birmingham, where she is developing a $\mathrm{PhD}$ in obstetrics and gynaecology in early modern Britain. She holds an honorary degree for "services to history". She makes 200-300 public appearances a year and also works as a TV historian in the UK and abroad including the USA. Lesley is also Curator of Tutbury Castle in Staffordshire and is currently involved with a major research project with the British Museum, which is her excuse for why it is taking her so long to finish her $\mathrm{PhD}$ !

Article 3.9: Persons not medically qualified but who have made an important contribution to and are working in the sphere of the Faculty and medical practitioners who are permanently retired from clinical practice, due to age or ill health, may on application to the Council be accepted for Associate Membership.

The annual subscription costs $£ 50$ and entitles Associate Members to copies of the Journal of Family Planning and Reproductive Health Care (plus free access to the online journal, managed by Ingenta) and access to the members' enquiry service.

Associate Membership application forms are available for downloading on the Faculty website at www.fsrh.org.

FACULTY OF SEXUAL \& REPRODUCTIVE HEALTHCARE

of the Royal College of Obstetricians and Gynaecologists 27 Sussex Place, Regent's Park, London NW1 4RG, UK 